\title{
RESIDENTIAL CO-OWNERSHIP WITHIN THE SUPERFICIARY RIGHT OF BUILDING - THEORETICAL HOTCH-POTCH OR PRACTICAL REALITY?
}

\author{
Pavel Petr \\ Faculty of Law, Palacký university Olomouc, Czech Republic \\ pavel.petr@upol.cz
}

PETR, Pavel. Residential co-ownership within the superficiary right of building - theoretical hotch-potch or practical reality? International and Comparative Law Review, 2016, vol. 16, no. 2, pp. 173-179. DOI: 10.1515/iclr-2016-0022.

\begin{abstract}
Summary: The new approach to a thing enables the concept of residential co-ownership within the superficiary right of building. Residential co-ownership may be created where a building with at least two apartments forms the component part of the immovable thing. The superficiary right of building is established as a derivative of the superficies solo cedit principle. Therefore, it requires the accession of building and land. The building is no longer a separate thing in the legal sense, but part of the superficiary right of building. If the building which is part of the superficiary right of building contains two apartments, then residential co-ownership may also be established as part of the superficiary right of building
\end{abstract}

Keywords: superficiary right of building, residential co-ownerhip , civil law, superficies solo cedit, ownership.

New laws take time to become a habit and enter public consciousness. Nothing is more harmful than frequent changes in laws, the Constitution and institutions, which do away with that which has barely entered public consciousness.

Motto of the Compilation committee on the Civil Code of Empress Maria Theresa (1753-1756)

\section{Introduction}

One would say that guests need to be received with dignity and respect. However, as regards the superficiary right of building (Baurech; Erbbaurecht or colloquially Erbpacht; uzytkowanie wieczyste), it is rather the return of a lost child. Known to First Republic lawyers, paradoxically the concept disappeared from our law later than the superficies solo cedit principle. Its return is rather due to necessity than wish. This is related to the main purpose of the superficiary

1 This article has been written as part of the Development Project with the institutional support of the Palacký University in Olomouc. 
right of building, which we see in a certain antagonistic interconnection with the superficies solo cedit principle. The superficiary right of building constitutes its derivative. In other words: one complements the other. On the other hand, it must be noted that the land always represents the principal thing, and it is also capable of being encumbered by immovable things other than the superficiary right of building. It is not the first time that the motto in the heading of the article appears in legal literature. This is perhaps because it is a traditional issue of recodification work of introducing new, or, in this case, a re-established one. The following text focuses on some - rather practical - aspects of this concept. Tomáš Dvořák ${ }^{2}$ once asked me a fiendish question: "Can residential co-ownership be established within superficiary right of building?” Almost instantaneously, I was about to say no. The reason for this was certainly not my snappy legal intuition, but rather a natural reflection of the incompatibility between temporary right in re aliena and an ownership right arising from a specific concept of apartment ownership.

New private law requires a far greater degree of legal abstraction, which is precisely the case with the above-mentioned question.

\section{Grey theory}

Theory distinguishes between undivided and divided shared co-ownership. Fiala $^{3}$ (and other authors referring to him ${ }^{4}$ ) talks about a third form - shared co-ownership of an accessory thing. Co-ownership of an accessory thing combines divided co-ownership (each co-owner of an immovable thing with undivided share owns a specific part of the immovable thing - unit), and undivided co-ownership (undivided share in the common parts of the immovable thing). Residential co-ownership is therefore a special form of shared co-ownership of an accessory thing. ${ }^{6}$ In a way, it is also a form of separate ownership.

In accordance with Section 1158(1) of the Civil Code, residential co-ownership is the co-ownership of an immovable thing arising from the ownership of units. Residential co-ownership may be established where a building with at least two apartments forms the component part of the immovable thing. In order for the statutory provision to become activated, we must fully fulfil its hypothesis. The elements of residential co-ownership require co-ownership of an immovable thing. Superficiary right of building is an immovable thing (Section 1242

2 As the reviewer of my dissertation.

3 FIALA, Josef. Pasivní věcná legitimace společenství vlastníků jednotek. Právní fórum, 2005, no. 4, p. 132.

4 KRÁLÍK, Michal. Podílové spoluvlastnictví. Praha : C.H.Beck, 2008. p. 23.

5 Jde o frekventovanější a pravděpodobně i správný výraz, viz např. DVOŘÁK, Tomáš. O vlastnictví bytů a nebytových prostorů jakožto akcesoriském spoluvlastnictví a o některých otázkách s tím spojených. Právní rozhledy, 2010, č. 7. s. 229.

6 Do not confuse with Section 1223 et seq. of the Civil Code. It is a theoretical classification. 
of the Civil Code). The term "co-ownership" implies that there must be plurality of persons. In my judgment, a sole owner of the superficiary right of building cannot lawfully establish residential co-ownership within superficiary right of building. The situation is different if the ownership of all units in the building merges within one person for the duration of the superficiary right of building.

In addition to the plurality of persons, co-ownership also requires the plurality of things. That means - and here we can see the characteristic elements of divided co-ownership - that the integrity of an immovable thing breaks down to apartments and undivided shares in the common parts of the immovable thing. Individual disposal of apartments and undivided shares is not possible. In this I see its accessory nature. This nature is also petrified by the term "unit" defined by the Civil Code, which, unlike the 1994 Housing Act, considers integral parts of units to include not only apartments, but also undivided shares in immovable things.

The Civil Code explicitly requires the existence of two apartments. Certain authors ${ }^{7}$ ignore Section 1158(2) of the Civil Code, which provides that the provisions of the Division (Section 1158, including Subsection 1, of the Civil Code) on apartments also apply to non-residential premises. It then goes on to erroneously state that unless a building which is part of an immovable thing contains at least two apartments (rather than an apartment and non-residential premises, or only two non-residential premises), residential co-ownership may not be stablished. The argument against these provisions is based on systematic interpretation. When analysing the provisions of Section 1158(1) and (2), we may conclude that the provisions of that Division on apartments also apply to non-residential premises. This is also supported by teleological interpretation. The purpose of residential co-ownership has long since ceased to be the mere satisfaction of the housing needs of "citizens". The present time demands diversity of ius in rem solutions, and the law caters to that demand. Separate ownership of various establishments, garages and other non-residential spaces is desirable, and the idea that buildings which are part of an immovable thing should, in addition to a workshop, contain two flats, is unsustainable.

It seems logical that the creation of a condominium will require the existence of two apartments (at least two rooms). However, this is not the case in Polish legislation. Case law $^{8}$ has inferred that it is possible to also define the ownership of apartments in a building with only one space (apartment or non-residential premises). ${ }^{9}$ The court has recognised the right of the owner of the land to define a unit in a building erected thereon in which there is only one non-residential

7 PRAŽÁK, Zbyněk. Bytové spoluvlastnictví Komentář $k$ \$ 1158-1222 nového občanského zákoníku a kzákonu č. 67/2013 Sb. Praha : Leges, 2014, p. 2.

8 The decision of the Polish Supreme Court (Sąd Najwyższy) dated 26 January 2008, file no. CSK 402/07.

9 Cf. Section 2 of the Premises Ownership Act 
space. The reasoning of the court relied on the provisions of Section 46 of the Polish Civil Code, which does not prohibit this, as well the fact that permanent walls can be considered to include the external walls of buildings which also define an internal unit. The aim of this peculiar ${ }^{10}$ argument is probably to allow the definition of two subjects of the right of ownership - a quasi-apartment, and quasi-common parts. It should be emphasized that the Polish Civil Code / Premises Ownership Act contains no provision which would prevent the creation of a single-unit condominium, and so the court permits it, in the spirit of the principle quod lege non prohibitum, licitum est. ${ }^{11}$ A similar argument, whose sense is not entirely clear to us, can also be found in the U.S. concept of "zero unit condominium" ${ }^{12}$

\section{Green tree of life}

As suggested by Zítek ${ }^{13}$, there is another element of residential co-ownership that poses a greater interpretative problem. It is the provision of Section 1158(1) if: Residential co-ownership may be created where a building with at least two apartments forms the component part of the immovable thing. As already mentioned above, the superficiary right of building is established as a derivative of the superficies solo cedit principle. Therefore, it requires the accession of building and land. The building is no longer a separate thing in the legal sense, but part of the superficiary right of building. If the building which is part of the superficiary right of building contains two apartments, then residential co-ownership may also be established as part of the superficiary right of building. After all, this possibility is suggested in the explanatory memorandum to the Civil Code. ${ }^{14}$

Austrians surprisingly allowed the creation of the concept of residential ownership from superficiary right of building by an amendment in 1990. The Austrian regulation of residential co-ownership consists in an agreement between land co-owners on the exclusive right to use and dispose of specific apartments (other spaces) in the building erected on the land. Co-owners cannot independently dispose of the common parts. It is also impossible for an apartment to be co-owned (except community property of spouses). Residential co-ownership as part of superficiary right of building became an issue, because Austria aban-

10 R. Strzelczyk in STRZELCZYK, Ryszard, TURLEJ, Aleksander, A. Własność lokali. 2. wyd. Warszawa : C.H. Beck, 2010. p. 54.; similarly also DZICZEK, Roman. Własność lokali. Komentarz. 6. wyd. Warzsawa : LexisNexis, 2012. p. 48., which mentions a strange, borderline case.

11 Bońcak-Kucharczyk, Ewa. Własność lokali i wspólnota mieszkaniowa. 3. wyd. Warzsawa : Wolters Kluwer, 2016. p. 59.

12 BUCK, George. The Zero Unit Condominium. The Practical Real Estate Lawyer,1991, No.1, p. 31-39.

13 ZÍTEK, Adam. Několik zamyšlení nad novou úpravou vlastnictví bytů. Rekodifikace \& praxe, 2015, no. 2., p. 19.

14 ELIÁŠ, Karel. Nový občanský zákoník s aktualizovanou důvodovou zprávou a rejstř́kem. Ostrava : Sagit, 2012, p. 499. 
doned horizontal (floor) ownership, and because a statute prohibited the establishment of the superficiary right of building to individual floors. Other entitled persons may establish apartment ownership in favour of the person entitled under the superficiary right of building. This right is governed by the provisions of the Apartment Ownership Act with the necessary modifications (cf. Section 6 of the Austrian Act on the Superficiary Right of Building).

Polish law also allows for the possibility to establish residential co-ownership within superficiary right of building. ${ }^{15}$ However, let me remind here that the scope of persons that may establish the superficiary right of building is limited to public corporations. This possibility was enacted in the Polish Apartment Ownership Act only after a 2004 amendment to the Property Administration Act. However, it is not possible to establish residential co-ownership on one plot of land (the owner of the apartment being at the same time the co-owner of the land under such ownership), and then establish the superficiary right of building. Apartments may only be defined as part of the superficiary right of building. ${ }^{16}$

The Polish doctrine is not unanimous on the question of whether, upon the termination of the superficiary right of building, it is only the land on which the building is erected, or also the apartments defined as part of the superficiary right of building which pass to the State/municipality, as a result of the termination of the legal division of the building to units due to the expiration of the period for which the superficiary right of building was established. Polish Supreme Court has ruled ${ }^{17}$ that the superficiary right of building is the key right, while apartment ownership is secondary in this case. As such, it becomes virtually extinguished with the expiration of the period for which the superficiary right of building was established. The transferor therefore receives the land on which the building with the defined apartments was erected. However, this is opposed by certain advocates of the doctrine. Strzelczyk believes that in the context of a weaker, temporary right, it is impossible to establish a stronger right which may last forever. He literally speaks about grotesque legislation that lacks logic and resembles a steel structure with feet of clay. ${ }^{18}$

To understand this condemnation, one should understand the purpose of the superficiary right of building (uzitkowanie wieczyste) in Poland. Unlike in Austria, where superficiary right of building was introduced in the early 20th century, the Polish legislators introduced it only in 1961, i.e. at a time of severe communist dictatorship. ${ }^{19}$ Once again, be reminded that in Poland the right to

15 Bońcak-Kucharczyk, Ewa. Własność lokali i wspólnota mieszkaniowa. 3. wyd. Warzsawa : Wolters Kluwer, 2016. p. 59

16 DZICZEK, Roman. Własność lokali. Komentarz. 6. wyd. Warzsawa: LexisNexis, 2012. p. 64.

17 NS decision of 3 September 2009, ref. no. I CSK 6/09.

18 R. Strzelczyk in STRZELCZYK, Ryszard, TURLEJ, Aleksander, A. Własność lokali. 2. wyd. Warszawa : C.H. Beck, 2010. p. 111.

19 Cf. Ustawa o gospodarce terenami w miastach i osiedlach 32/1961 Sb. 
establish superficiary right of building lies only with municipalities, State and other public corporations, which hinders its development. Originally, it had a very administrative nature (land allocation). In terms of its purpose, it resembles the well-known personal use of land, which was introduced by the socialist Code of 1964. Basically, it was a different way to the same objective. By the way, the socialist "private-law" legislation was not created in a vacuum. Quite the opposite - recodification institutions of people's democracies worked together. ${ }^{20}$

Currently, there is a possibility to transfer superficiary right of building to ownership. ${ }^{21}$ This means, that the right will change from temporary to permanent. This is justified by the impossibility of private ownership of land at the time when superficiary right of building is established. It resembles the situation with the transition provision of the major 1991 amendment concerning the right of personal use. Although relativised by some authors ${ }^{22}$, the original aim was to eliminate the concept because of its ideological bias ${ }^{23}$.

The superficiary right of building was replaced by the concept of "temporary" ownership (własność czasowa) ${ }^{24}$, which was introduced after World War II. Basically, it was superficiary right of building "inside out", which also could last a minimum of 30 and maximum of 80 years. This right to the land could be transferred to an individual by the State or a municipality, to which the land passed back upon the expiration of the right. The right was established by an entry into a public register. After that, the right could be converted to the superficiary right of building.

The situation in Warsaw was specific. The "Warsaw Decree" of 26 October $1945^{25}$ nationalized the land (but not buildings on it) in the entire territory of Warsaw. The purpose was purely political. Without the nationalization of land, the rebuilding of the capital would have been impossible. However, the problems did not end there. The owners were stripped of their ownership right to the land (ca. 40,000 plots) and, moreover, obliged by another decree to restore the war-damaged houses (about 24,000) which remained in their possession. If the owner failed to act, the City acted in his stead, but on the owner's account. In this

20 However, the sad truth is that while the Polish Code has retained at least the basic pillars typical for private-law codifications in Europe, the opposite was the case for the Czechoslovak one.

21 Ustawa o przekształceniu prawa użytkowania wieczystego $\mathrm{w}$ prawo własności nieruchomości č. 175/2005 Sb.

22 KOKOT, Sebastian. Ekonomiczne zagadanie użitkowanie wieczystego $w$ gospodarce nieruchomoścami gmin. Szczeciń : Winus, 2009. 299 p.

23 KALUS, Stanislawa, HABDAS, Magda. Czy nas na to stać? Gazeta Prawna, 2003, no. 239, p. 20.

24 It was established on the basis of a special Decree on In Rem Rights of 1946. The Decree had the force of a statute.

25 It is sometimes referred to as Bierut Decree in honour of the Chairman of the National Council Boleslaw Bierut. 
case, the title to the building was transferred to the city as a security until the price of repairs has been paid. The compensation for the removal of ownership of land was addressed either by emphyteusis, or the offer of municipal bonds. Ultimately, the decree has caused a slowdown of construction in the capital. The situation was partially resolved in costly litigation only after 1989.

\section{Conclusion}

If we go back to the possibility to establish residential co-ownership within the superficiary right of building, then there is the question of cui bono, i.e. who can benefit from such a dogmatically objectionable concept. We do not have to look too far for an answer. Surely, the beneficiaries will exclude those who need to meet their housing needs, because the prospect of a long-term mortgage after the repayment of which they will lose ownership of the apartment is certainly not rational. On the other hand, if the superficies payment is very low (lower than a rent in a comparable apartment), it could be an alternative. However, that will probably not be the case. Conversely, the definition of units within the superficiary right of building may be suitable for developers, if we ignore the fact that developers mostly rent non-residential premises in an office building erected on land encumbered by the superficiary right of building. We can find another suitable solution - the sale of such a "temporary" unit. Again, this may not be interesting for a person that wants to own the thing permanently. However, if we look at it from a purely entrepreneurial and practical perspective, it can be a highly attractive solution. If the developer sells all the units it creates within the superficiary right of building, it may ultimately be profitable and become released from all the rights to the land. Alternatively, the developer may simply lease parts of the superficiary right of building, i.e. specifically defined units (apartments, garages, establishments, warehouses, workshops, etc.). It may again be advantageous from the perspective of a person that purchases the unit knowing that it will not be for a limited period of time. If such a person is an entrepreneur that wants to lease the unit, then this will be easier than subleasing leased premises within the superficiary right of building. If the person wants to live in the apartment, then he or she may only be motivated by the economic benefits of such a transaction at the most. 